\title{
Contribution of GIS in Mineral Exploration through Mineralization Distribution Characteri- zation: Application to The Sétifien/Hodna Massifs and The Eastern Saharan Atlas (NE Algeria)
}

Ysbaa Saadia ${ }^{1 *}$, Rachid Nedjai², Omar Haddouche ${ }^{3}$, Abdelhak Boutaleb $^{3}$ and Madjid Chemam ${ }^{4}$

ISSN: 2578-0255

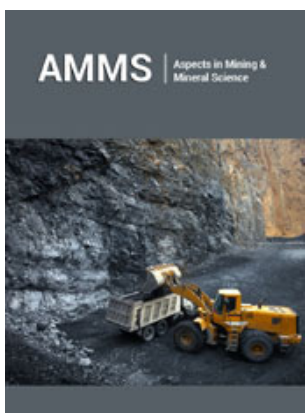

*Corresponding author: Ysbaa saadia ,Faculty of Hydrocarbons and Chemistry, Laboratory of Mineral Resources and Energy, University M'hamed Bougara (UMBB), Boumerdes, Algeria

Submission: 海June 21, 2019

Published: 眥July 3, 2019

Volume 3 - Issue 2

How to cite this article: Ysbaa saadia. Contribution of GIS in Mineral Exploration through Mineralization Distribution Characterization: Application to The Sétifien/ Hodna Massifs and The Eastern Saharan Atlas (NE Algeria). Aspects Min Miner Sci.3(2). AMMS.000556.2019. DOI: 10.31031/AMMS.2019.03.000556

Copyright@ Ysbaa saadia, This article is distributed under the terms of the Creative Commons Attribution 4.0 International License, which permits unrestricted use and redistribution provided that the original author and source are credited.
${ }^{1}$ Faculty of Hydrocarbons and Chemistry, Laboratory of Mineral Resources and Energy, University M'hamed Bougara (UMBB), Boumerdes, Algeria

${ }^{2}$ Lab. CEDETE, Departement of Geography, Orléans, France

${ }^{3}$ Lab of Metallogeny and Magmatism, Algeria

${ }^{4}$ Abitibi Geophysics Inc, Canada

\begin{abstract}
The integration and processing of geological/depositional, geophysical and geochemical data in a geographic information system, contributed to the accurate determination of the spatial distribution and particularities of the $\mathrm{Pb}-\mathrm{Zn}-\mathrm{Fe}-\mathrm{Ba}(\mathrm{Cu}, \mathrm{Hg}, \mathrm{F}, \mathrm{Sr})$ mineralization of the Sétifien/Hodna region and the eastern Saharan Atlas. The treatment and analysis by application of the principle functionalities of the spatial module to these geoscientific data in terms of axes/trends shows the existence of a spatial correlation between mineralization and certain families of preferential lineaments/trends. The combination of gravimetric and aeromagnetic data reveals important tectonic lineaments mainly directed from $\mathrm{N} 135^{\circ}$ to $\mathrm{N} 170^{\circ}$ and $\mathrm{N} 40^{\circ}$ to $\mathrm{N} 60^{\circ}$. The location of the mineralization near or along these tecto-lineaments and at the limits of sedimentary basins margins, reinforces the hypothesis of a strong relationship between these two geological phenomena. The ordinary kriging interpolation of $\mathrm{Pb}-\mathrm{Zn}-\mathrm{Cu}$ Fe (\%) concentrations, measured by direct measurements, shows a linear mineral zoning with directions similar to those recorded for the lineaments. These directions probably reflect deformation corridors that have controlled the emplacement of mineralized deposits and that may represent potential targets for mineral exploration.
\end{abstract}

Keywords: GIS; Geology; Gitology; Geophysics; Tectonic; Mining exploration

\section{Introduction}

The characterization of the relationship between mineralization and their geological environment by analysis and processing of multi-criteria geoscience data has been the subject of numerous studies around the world [1-6]. Permanent explorations associated with the different direct/indirect techniques have largely contributed to the knowledge of the associations susceptible of precisely defining these mineral poles and to the creation of large volumes of data that can help in their localization [7-12]The advent of new information technologies, mainly geomatics (Remote Sensing and GIS) has contributed strongly to the processing of these data and in acquiring further knowledge about these depositional centers. In the Hodna/Setifian and Eastern Saharan Atlas region, several Pb-Zn-Fe-Ba (Cu, Hg, F, Sr) mineral deposits and indices have been discovered, the majority of which have been subjected to direct exploitation since the 1940s giving rise to important amounts of data. The cartographic representation of these mineralization's displays a direct spatial trend between the mineralization and large tectonic accidents. The regional metallogenic framework remains relatively unknown. The different types of mineralization have been the subject of several metallogenic, geochemical and structural studies, however data and interpretations are mainly at the local scale and linked to the deposits themselves. These mineralizations generally show a spatial relationship with the major surface tectonic accidents that would have controlled the circulation of hydrothermal fluids responsible for the emplacement of the mineralization. 
The amount of data on these mineral deposits and occurrences found in these regions is the result of numerous geological and depositional studies [13-32] that haven't undergone any digital processing capable of bringing out and/or in new approaches and additional results to better characterize these mineral resources. Inputting and structuring data into a spatial database facilitates geoprocessing and numerical weighting which can confirm and/or invalidate the potential spatial relationship to be studied. The work carried out on these mineral associations and on the cartographic location of the principal deposits and mineral indices makes it possible to present several hypotheses, on the basis of a simple cartographic reading:

a) Their proximity to large geological structures (diapirs, collapse grabens, anticlinal structures...

b) Their location near or on major tectonic accidents

c) Their location with respect to sedimentary basins and lithostratigraphic sets.

To answer these questions regarding the potential relationship between geological structures and mineral deposits, the use of new spatial techniques (GIS) and the application of geostatistical meth- ods (multivariate analysis: geological/depositional, topographical, geochemical and geophysical, interpolation, calculation of spatial indices, ...) makes it possible to specify the distribution properties of the Setifian/Hodna and Eastern Saharan Atlas mineralization. A geostatistical study using a classical interpolation (kriging) method has been adopted to evaluate the spatial distribution of $\mathrm{Pb}, \mathrm{Zn}$, $\mathrm{Cu}$ and Fe concentrations (\%). These interpolation maps are then compared to the different geological and geophysical maps to identify main axes and "structural trends" controlling the mineralization process.

\section{Geographical and Geological Overview}

The study area is located in the north-eastern part of Algeria at the edge of the nappes front to the north, limited to the south to the Algerian-Tunisian border by the NE-SW chains of the Aurès mountains and Nemencha mountains. The persistence of tectonic actions on the Tellian domain and the eastern Saharan Atlas has caused the subsidence of large areas and the creation of narrow and discontinuous depressions (example: Hodna depression, Timgad Basin, Morsott graben, etc.). This region consists mainly of Mesozoic sedimentary rocks, with locally dispersed intrusions of diapiric rocks (Figure1). Two large structural sets can be distinguished:

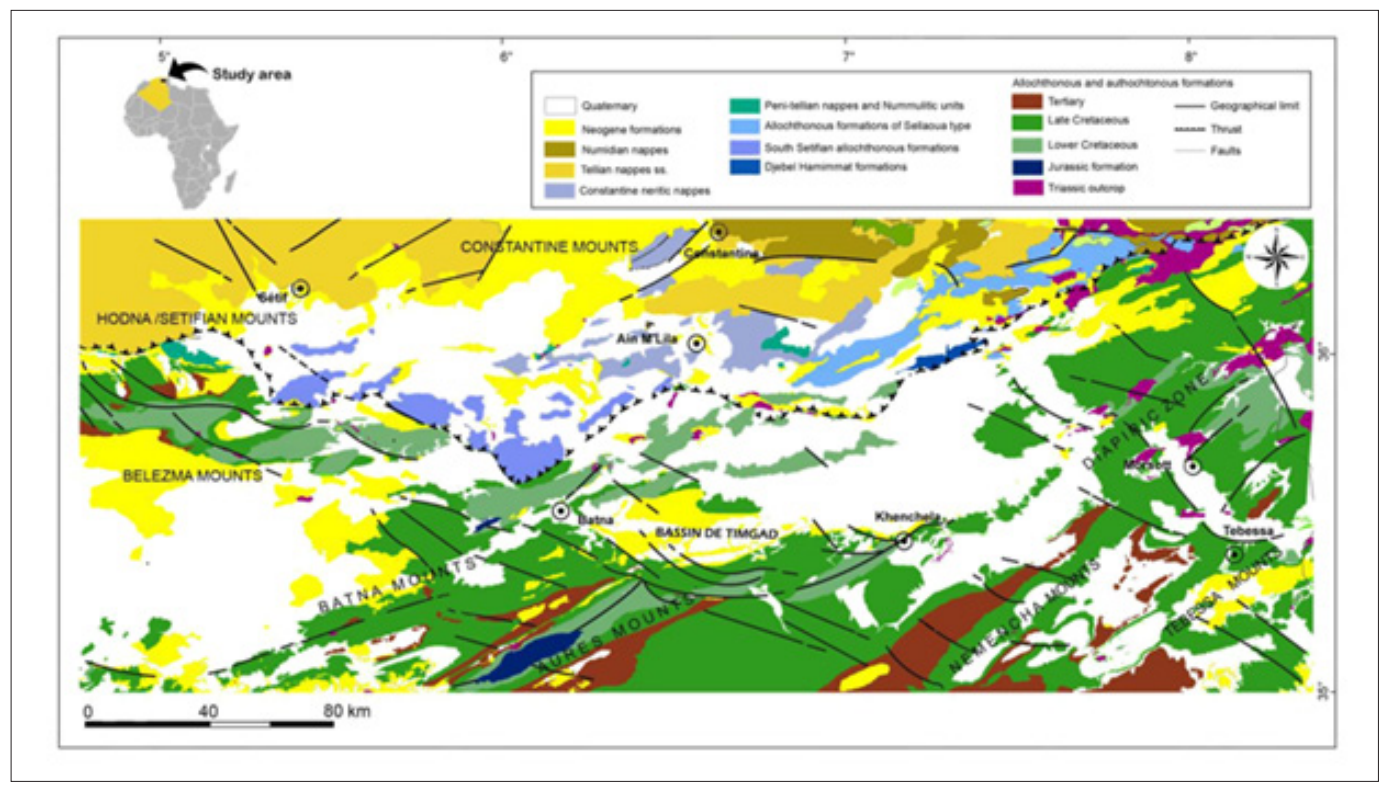

Figure 1: Simplified and georeferenced geological map of northeastern Algeria.

a) To the north-west, the Setifien/Hodna Mountains consisting mainly of Mesozoic and Tertiary autochthonous formations, affected by several tectonic phases. These regions show mainly NE-SW folded structures related to a late Eocene compressive event. To the south, in the Belezma Mountains, the Belezma Anticline began to form at the base of the Upper Eocene, then evolved into an overlapping Miocene (intra-Tortonian) [33].

b) The Atlas domain corresponds to the structures located south of the North Atlas accident, intensely folded at the end of the Middle Eocene. The diapiric structures are numerous and can influence locally the sedimentary and structural evolution of the sedimentary cover. In the Khenchela region, diapiric movements allow the development of the santonian reefs [16,34]. In the "diapirs zone", these phenomena are important and are found interrupting the Upper Cretaceous and Tertiary formations [25,28,32,35,36].

c) The domain of Aurès-Nemencha generally represents the meridional limit of the eastern Saharan Atlas and is affected by a strong Cretaceous subsidence, more pronounced in the Jurassic in the Ould Naïls Mountains [17]. This area is characterized by large folds of direction $\mathrm{N} 50^{\circ}-\mathrm{N} 60^{\circ}$, limited to the south by the long chain of Djebel Rheliss. The latter forms a discontinuous garland of E-W direction hills, clearly spilled towards the North and covering the Miocene formations or the Pliocene base [16,19]. 
At the tectonic scale, the faults that affect this region are NWSE/NNW-SSE, NE-SW, E-W, and rarely ENE-WSW and NS. NW-SE and NNW-SSE-oriented faults which usually result in dextral strikeslips or normal faults [14,19-21,30-32].

\section{Metallogenic Aspect: Spatial Characterization of Mining Sites}

There are several small deposits and mineralized indices in the northeastern part of Algeria (Figure 2), whose paragenesis, typology and method of emplacement vary from one region to another, depending on the geological context and tectonics. In Setifian/Hodna and the eastern Saharan Atlas, these deposits are globally epigenetic of "MVT" type, Mississippi Valley Type [37-40].
The mineralized bodies are in filonian form, in lenticular clusters, and in stratabound principally NE-SE, NW-SE, and E-W oriented [28,30-32]. Mineralization is mainly encased in the Jurassic and Lower Cretaceous formations (Hauterivian, Barremian and AlboAptian). In the Sétifien, the most economical deposit is that of Boukhdéma, composed of a mineral association of essentially sphalerite, galena and pyrite, in the form of "stratabound" [30]. In Hodna, the economic deposits are located in the region of Ain Azel which contains several stratiform deposits of $\mathrm{Pb}-\mathrm{Zn}$, of which the most important are Ain Kahla, Kherzet Youcef and Chabet El Hamra, Abiane, Z'Dim, Braou, Dra Sfa and Sekkaken. The mineralization is essentially composed of galena and sphalerite, locally associated with pyrite, smithsonite, cerusite and hydrozincite.

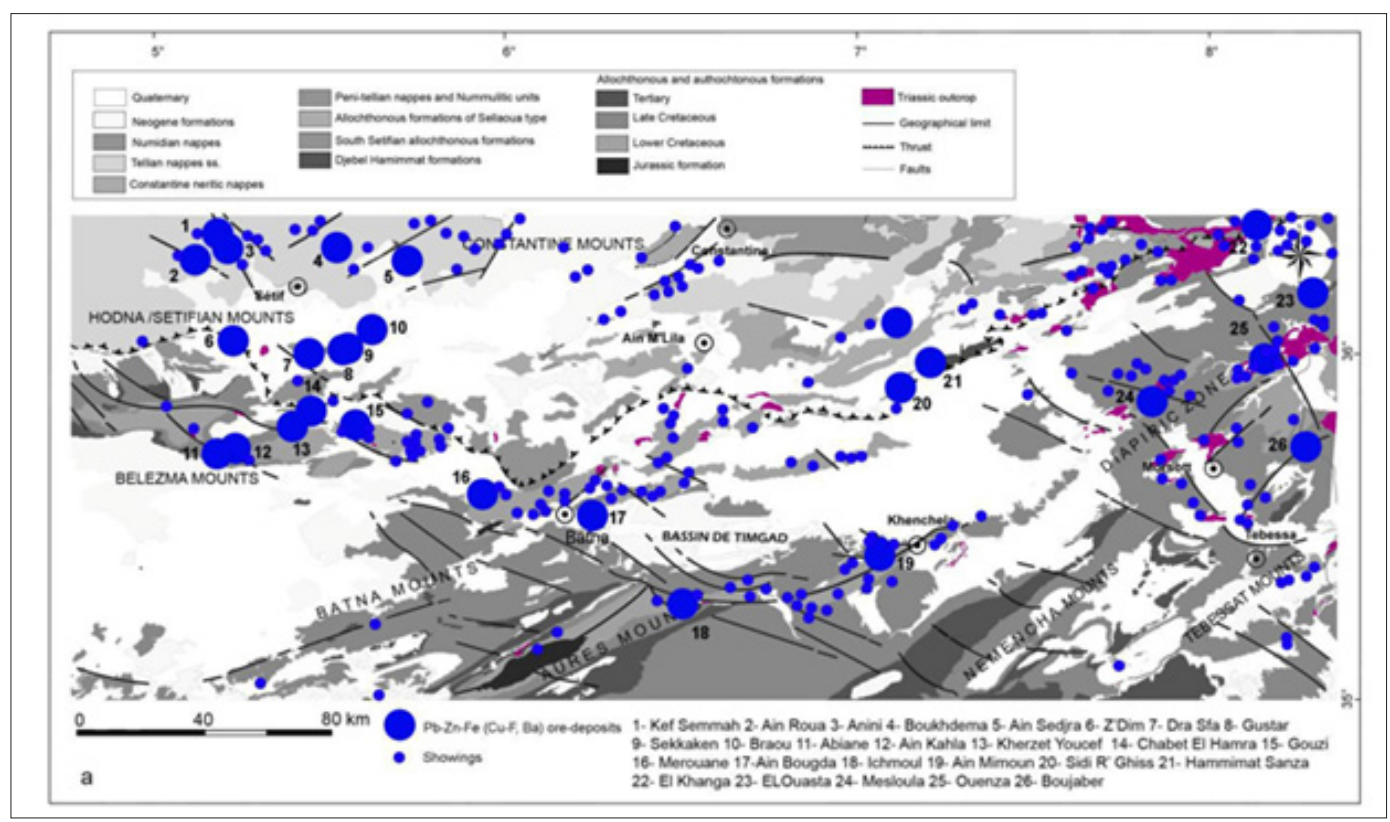

Figure 2: Main deposits and mineralized indices of Eastern Algeria.

Towards the south, in the Belezma Mountains, there are several $\mathrm{Pb}-\mathrm{Zn}$ deposits, notably that of Merouana, encased in the dolomitic bar of the Upper Aptian, in the form of cracks fillings of various directions [30]. The mineralization is mainly translated by sphalerite and incidentally pyrite and galena associated with white dolomite. In the south-east, in Batna Mounts, the recent works of the ORGM (1992 to 1998), put into evidence a rather interesting $\mathrm{Pb}-\mathrm{Zn}$ mineralization in the Aïn Bougda region. The mineralization is encased in the dolomitic limestone of the Aptian, in the form of lenticular "stratabound" bodies that extend for 6 to $30 \mathrm{~m}$. Mineralization consists mainly of marcasite, pyrite, melnicovite, sphalerite and galena. It is presented under the form of open space filling material and in cement breccias which are probably of hydraulic origins [30]. In the Aurès Mounts, there are several Ba$\mathrm{Pb}-\mathrm{Zn}(\mathrm{Hg}$ ) deposits, mainly encased in the carbonated Cretaceous and Miocene formations. There are two principal deposits, first the Ichmoul deposit, essentially made of barite and galena, in the form of lenticular clusters of E-W direction. To these minerals, disseminated red sphalerite is associated with black shales rich in organic matter [31]. Towards the NE, the mineralization of Aïn
Mimoun are translated by a filonian field mainly of barite, galena and gray copper, which are largely outcropping at the hinge and the NW side of the Khenchela anticlines (Djebel Aïdel). The mineralized veins are associated with normal NE-SW, NW-SE and E-W fractures. They are hosted in calcaro-dolomitic and sandstone albo-aptian levels. In the eastern Saharan Atlas and in the Algerian-Tunisian areas, there are several deposits of lead, zinc and iron, mostly controlled by diapiric areas along NE-SW axes. Among the most important are El Ouenza, Boukhadra, El Ouasta, Mesloula, M'Zeita and Boudjaber. All these deposits are epigenetic [28,30-32]. They belong to the same paleogeographic domain of carbonate platform with reefal trend; only the El Ouasta deposit belongs to the domain of the Tunisian furrow which sinks to the north under allochtonous lands.

\section{Methodology, Treatment and Analysis}

In order to build the spatial database necessary for this study, we used geological supports based on the 1,500,000 geological map of the Alpine chain and the Algerian-Tunisian borders [41] and the 1,200,000 geological maps of Khenchela, Tebessa and Batna 
[42]. Geological data have been input, digitized and georeferenced using ArcGIS 10.4.1 software. Aeromagnetic and gravimetric maps reinterpreted and processed using the Oasis software, respectively based on the data of the American firm Aero Service Limited (19711974), with a measurement step of 150 feet (approximately 46m) and on the basis of gravimetric data by [26] have been used for the characterization of structural phenomena. Gravimetric inversion of the residual anomaly (3D) was designed with Geosoft's Earth modeling technology without constraints and a density contrast model was defined for the study area. For topographic data, we used the Advanced Spacebone Thermal Emission and Reflection Radiometer (ASTER) DTM, which is a Digital Elevation Model (DEM). It covers our study area with a resolution of 1 second of arc or about 30 meters in GeoTiff format under WGS84 projection.

\section{Cartography and GIS}

Under ArcGIS 10.4 software, numerical data for topography, geology, and deposition have been structured in multi-layers that represent different information plans or sets. These superimposed thematic layers allow us to acquire a set of homogeneous vector objects with the same type of spatial data, organized into different feature classes, feature datasets, object classes (Object class or tables), as well as raster files. Attributes are stored in the attribute table of a feature class. The latter represents classes of entities having topological relations and that can be used to group together entity classes belonging to the same theme. All feature classes belonging to the same feature dataset are stored with the same spatial reference (datum, projection, domains, etc.). The tables consist of a set of fields and records, in the form of columns. They can be related or joined to tables or feature classes in the same Geodatabase. Geophysical maps are managed as a set of different raster files in a catalog (ArcCatalog). The geophysical lineaments have been integrated into ArcMap, in vector format. For each component, the spatial references (system of geographical coordinates) are subjected to System of projection (GCS_Nord_ Sahara_1959), Ellipsoïde (D_Nord_Sahara_1959), meridian of origin (Greenwich), angular Unit (degree). The geological support was carried out on the basis of the 1,500,000 geological map of the eastern Alpine range and the Algerian-Tunisian borders [41] for the northern part. The southern part was drawn up on the basis of geological cartography done on the 1,200,000 Khenchela, Tebessa and Batna maps [42].

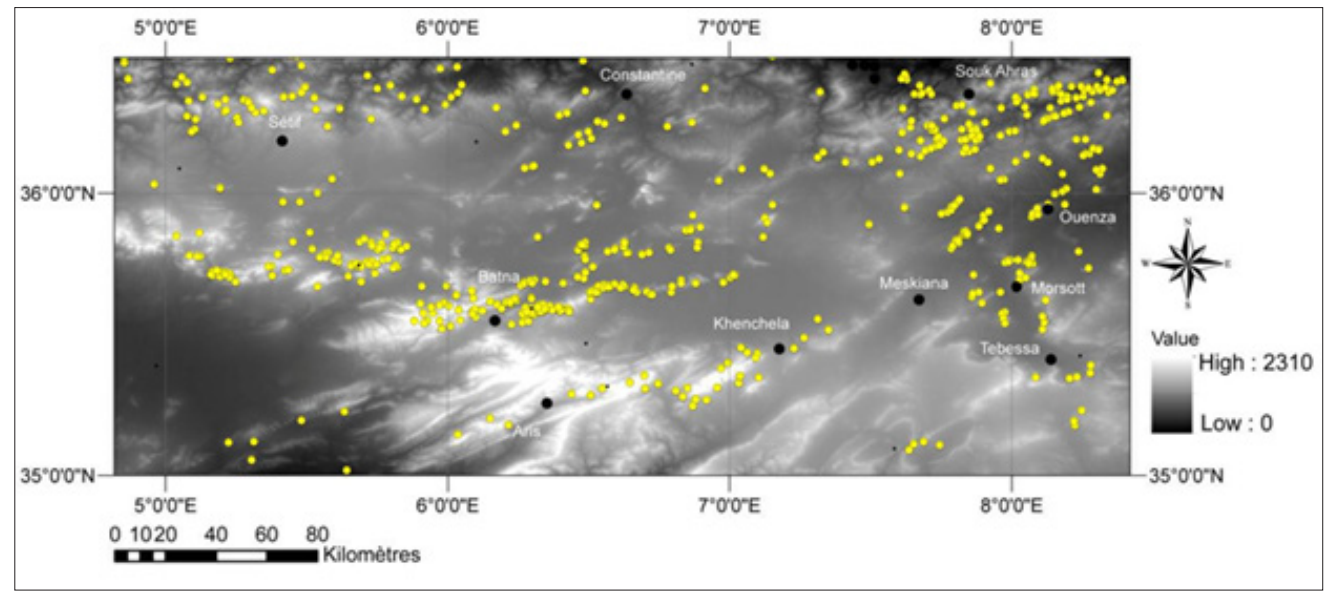

Figure 3: Numerical terrain model DTM ASTER of Hodna/Setif region and the Eastern Saharan Atlas. The yellow dots represent the location of the main $\mathrm{Pb}-\mathrm{Zn}-\mathrm{Fe}-\mathrm{Ba}(\mathrm{Cu}, \mathrm{Hg}, \mathrm{F}, \mathrm{Sr})$ deposits and mineralized indices.

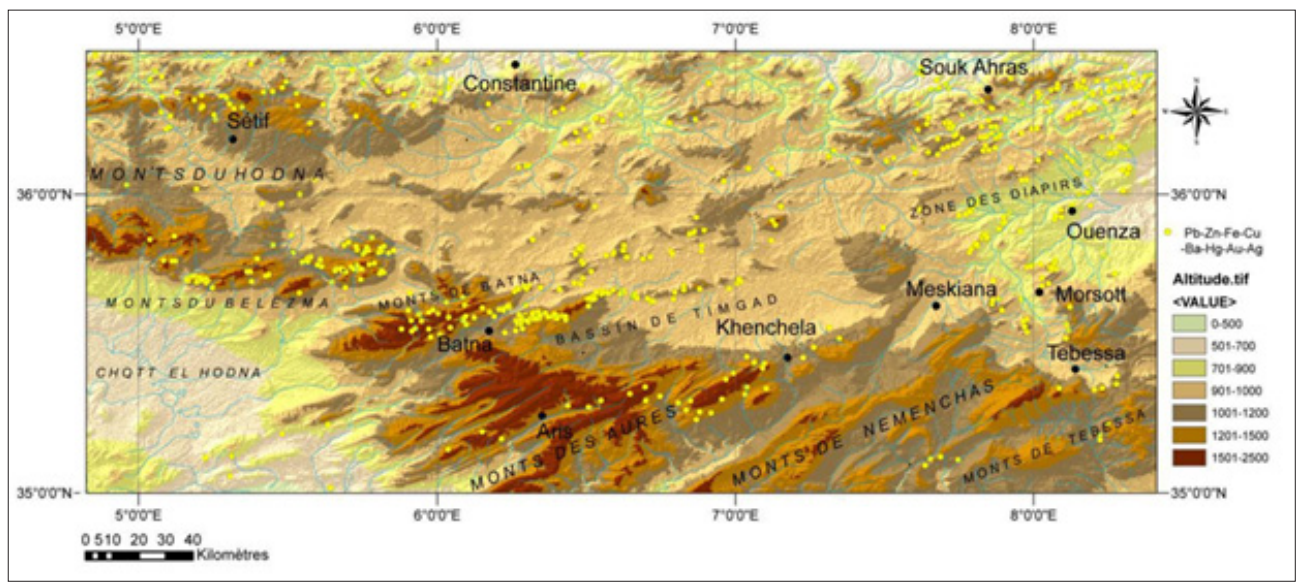

Figure 4: Elevation bands map of Hodna/Setif region and the Eastern Saharan Atlas. The yellow dots represent the location of the main $\mathrm{Pb}-\mathrm{Zn}-\mathrm{Fe}-\mathrm{Ba}(\mathrm{Cu}, \mathrm{Hg}, \mathrm{F}, \mathrm{Sr})$ deposits and mineralized indices. 


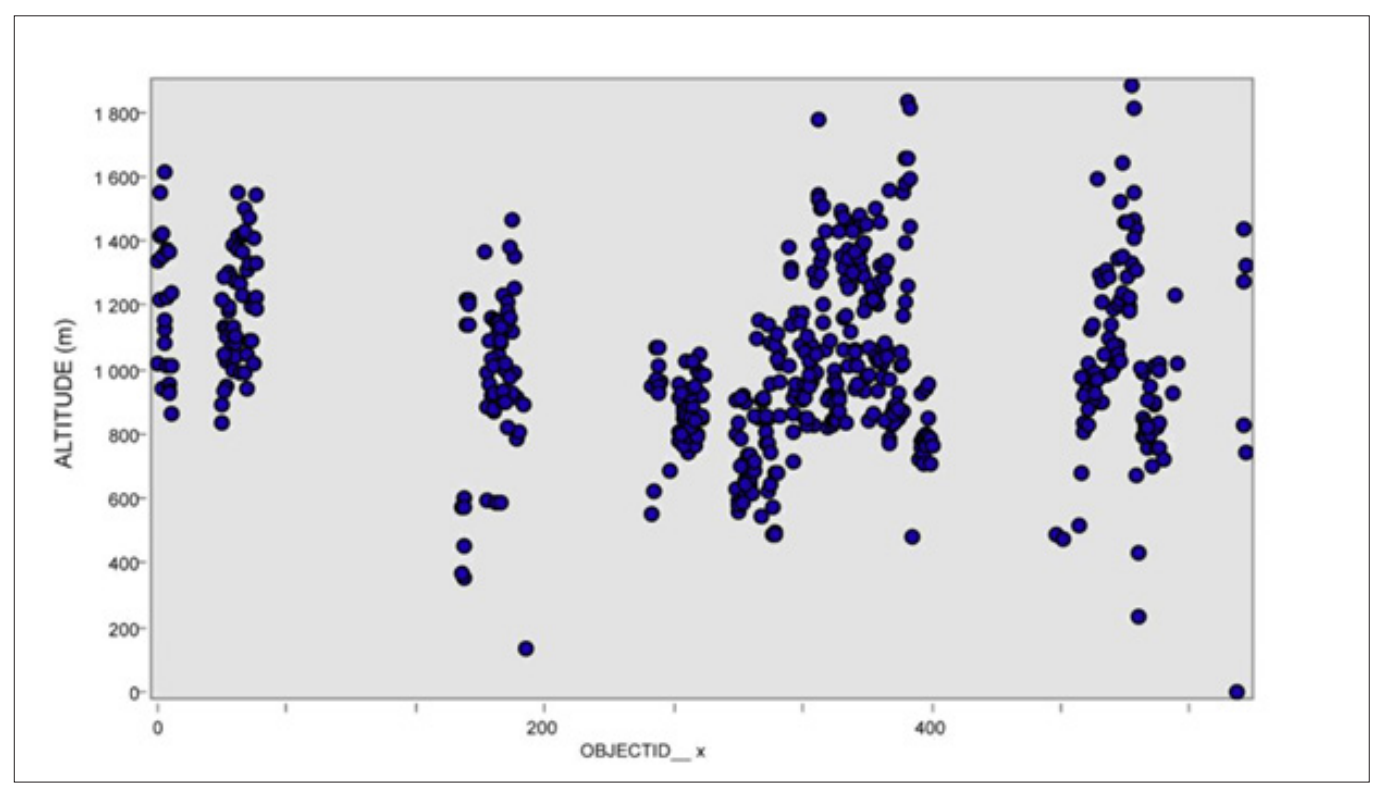

Figure 5: Diagram showing the distribution of the mineralized deposits and indices according to altitudes.

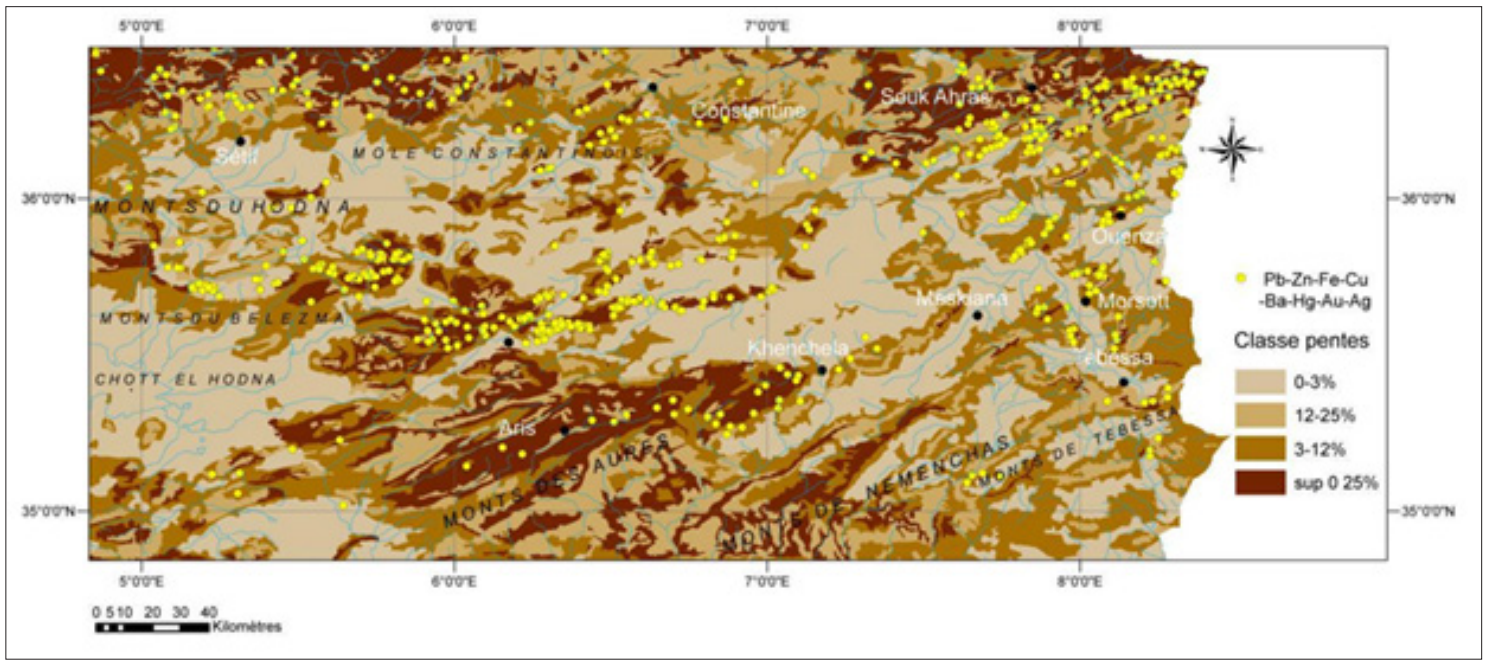

Figure 6: Slope Map of Hodna/Setif region and the Eastern Saharan Atlas. The yellow dots represent the location of the main $\mathrm{Pb}-\mathrm{Zn}-\mathrm{Fe}-\mathrm{Ba}(\mathrm{Cu}, \mathrm{Hg}, \mathrm{F}, \mathrm{Sr})$ deposits and mineralized indices.

An ASTER Numerical Terrain Model from the study area was produced using USGS data, compatible with ArcMap ESRI and ArcGIS Explorer. A relief image of the ASTER DTM composed of linear features of 30 meters resolution was developed reflecting the reliefs and irregularities of the surface of this region (Figure 3). From the digital terrain model, the map of elevation bands was produced allowing us to visualize the distribution of the mineralized deposits according to the altitudes (Figure $4 \& 5$ ). In addition, we produced a slope map that provides insight into the location of mineralized deposits as a function of slope (Figure 6).

\section{Geophysical data analysis}

The integration of geophysical data provides a better understanding of the spatial relationships between mineralization, lithologic/structural units, and faults [43-48]. The geophysical maps produced using the "GEOSOFT" software were introduced in "Raster" format with a Tiff extension in ArcGIS. Structural discontinuities were interpreted directly in GIS (ArcGIS 10.4), using magnetic and gravimetric data from the American firm Aero Service Limited (1971-1974) and [26] respectively. The interpretation of the geophysical discontinuities was done by zone taking into account the structural style of the geological map. The total magnetic field data has a measurement step of $150 \mathrm{feet}$, or about $46 \mathrm{~m}$. They were first filtered with the GEOSOFT software in different layers with the MAGMAP option (Figure 7). The gravimetric inversion of the residual anomaly (3D) was made with GEOSOFT's Earth modeling technology without constraint and a density contrast model was defined for the study area. The "GEOSOFT" model was used to 
reverse the residual anomaly. The underground model of the study area was divided into small rectangular cells of 1000X1000X500m
(X, Y and Z) dimensions. (Figure 8) shows the surface projection of the density contrast distribution, obtained by 3D inversion.

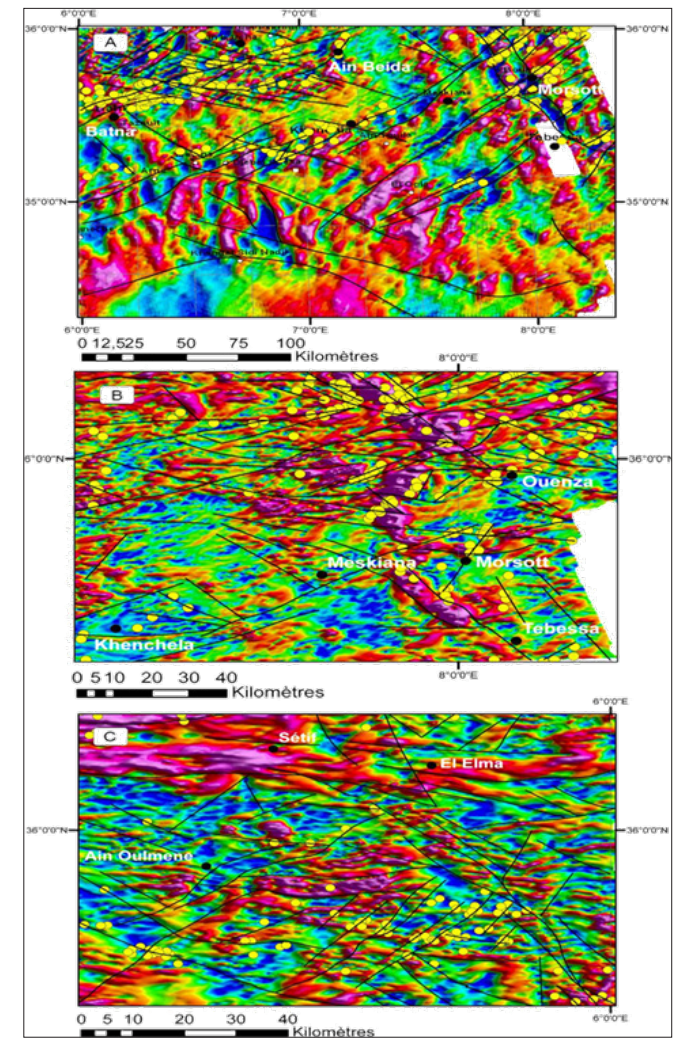

Figure 7: First horizontal derivative of the total magnetic field, fault network and structural discontinuities (black) and localizations of the main indices and mineralized deposits with $\mathrm{Pb}-\mathrm{Zn}-\mathrm{Fe}-\mathrm{Ba}(\mathrm{Cu}, \mathrm{Hg}, \mathrm{F}, \mathrm{Sr}$ ) (yellow dots). A) Eastern Saharan Atlas. B) Diapirs zone. C) Hodna and Setifian Region.

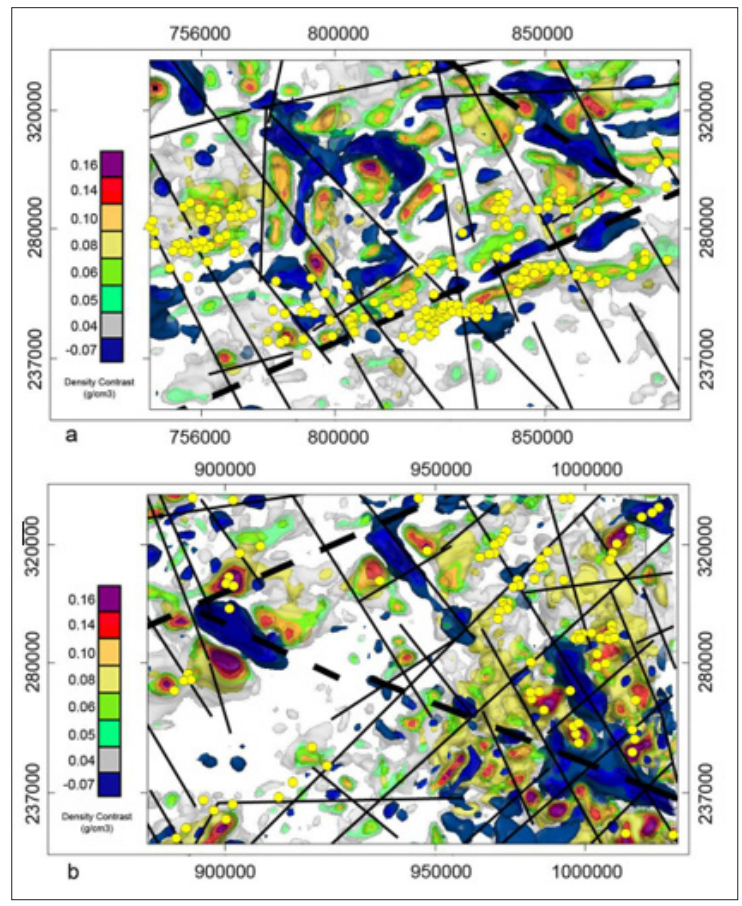

Figure 8: Interpretation of the gravimetric map's density contrast by 3D inversion a) Sétifien, Belezma Mountains and Batna Mountains. b) Diapirs zone. The yellow dots represent the location of the main $\mathrm{Pb}-\mathrm{Zn}-\mathrm{Fe}-\mathrm{Ba}(\mathrm{Cu}, \mathrm{Hg}$, F, Sr) deposits. 
The analysis of gravimetric data shows the presence of a broad sedimentary cover. In the central part, linear structures (anticlines NE-SW) give values oscillating between -40 and -55 milligales. NWSE linear gravity gravity ditches or troughs give values between -60 and -75 milligals. The interpretation of density contrast maps, obtained by 3D inversion, shows numerous geophysical lineaments, mainly in the $\mathrm{N} 135^{\circ}$ to $\mathrm{N} 170^{\circ}$ and $\mathrm{N} 40^{\circ}$ to $\mathrm{N} 60^{\circ}$ directions. These tecto-lineaments have mean lengths varying between 12 and $120 \mathrm{~km}$. They do not show any apparent movement, but on the surface, the same directions are represented by strike-slips or normal faults. The more or less circular blue anomalies probably reflect the diapiric structures, or graben. The other density contrasts reflect linear geological structures (mainly $\mathrm{N} 50^{\circ}$ anticlines).

\section{Geostatistical approach to mineral foci}

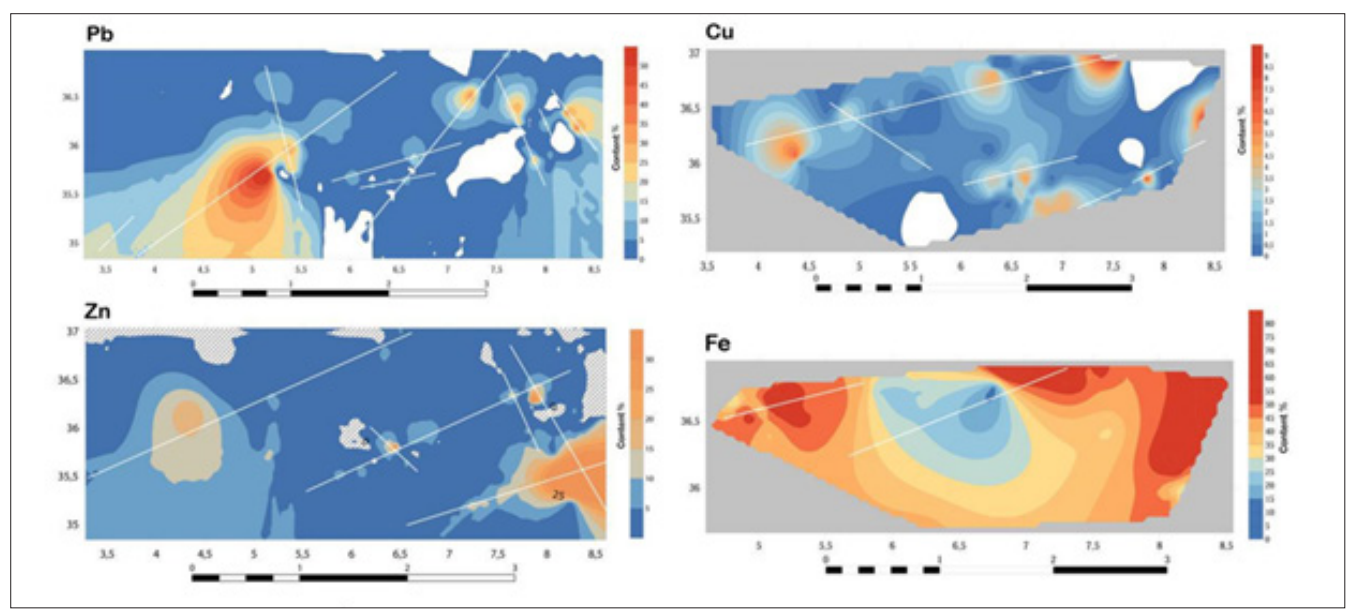

Figure 9: Ordinary kriging interpolation maps of $\mathrm{Pb}-\mathrm{Zn}-\mathrm{Cu}-\mathrm{Fe}$ chemical elements of Hodna/Setifian and Eastern Saharan Atlas.

The geostatistical analysis of the geochemical data consists of producing interpolation maps by ordinary Kriging of the Pb-Zn$\mathrm{Cu}-\mathrm{Fe}$ chemical elements (\%) in order to measure the potential depositional focis' regional spatial extent (Figure 9). The applied interpolation technique represents a wide range of applications in geoscience studies [49-51]. It provides a better linear estimate of a regionalized variable that can be used for synthesis analytic work and spatial modeling in mineral exploration. The interpolation maps used in this study are constructed to identify the "structural trends" of $\mathrm{Pb}-\mathrm{Zn}-\mathrm{Cu}-\mathrm{Fe}$ chemical elements in percentage. The geochemical data were run and analyzed on 900 points for which the $\mathrm{x}-\mathrm{y}$ coordinates (UTM WGS 84 ellipsoid) were calculated with reference to the location of deposits and mineralized indices. The concentrations of $\mathrm{Pb}-\mathrm{Zn}-\mathrm{Cu}-\mathrm{Fe}(\%)$ in the database were processed in ArcInfo and merged with the spatial database in the GIS. Interpolation maps show different colors that represent different varaibility intervals of $\mathrm{Pb}-\mathrm{Zn}-\mathrm{Cu}-\mathrm{Fe}(\%)$.

\section{Spatial Analysis and Discussion}

Collected results allow the proposition of scenarios susceptible of pin pointing adequate precision on the behavior and the spatial distribution of the deposits and mineralized indices of Sétifien/Hodna and Eastern Saharan Atlas. Produced maps show preferential linear trends in mineralization, comparable to regional structural directions (anticlines, synclines, sedimentary basins, diapiric structures, and grabens) and regional faults. In the Sétifien/Hodna, a large part of the deposits and mineralized indices (Abiane, Ain EL Kahla, Chabet el Hamra, Kharset Youcef and Gouzi) are located near or along the NW-SE/EW faults, clearly visible on the aeromagnetic and gravimetric maps. In the eastern Saharan Atlas, mineralized deposits are preferentially located along or near the NE-SW and NW-SE tecto-lineaments, at the edges of subsident sedimentary basins, generally at the anticline hinges (Merouana, Ichmoul and Ain Mimoum), or at the edge (Ain Bougda deposit) in the carbonate formations of the lower Cretaceous. In the diapiric zone, mineralized deposits are generally located on the edges of diapiric structures and grabens (Kef Rekhma, M'khiriga, Boudjaber, Hamimmat deposits), sometimes near NE-SW and NWSE accident zones (deposits of Mesloula, Es Souabaa). On a regional scale, these tectonic accidents would probably have controlled the emplacement of the mineralized deposits. According to Herkat [17], these tectonic accidents probably controlled the evolution of atlastic sedimentary basins in a tilted block system.

The combination of mineralization with geomorphological data (ASTER DEM, slope map, elevation bands map) clearly shows a distribution of mineralization in the depressions margins, characterized by tectonic and/or sedimentary subsidences. They are located on the foothills, following a general alignment from west to east, following the general shape of the relief. The majority of the deposits occupy slopes varying between 3 and 12\% and an altitude between 1000 and $1200 \mathrm{~m}$. The deposits south of the Hodna Basin have an altitude of $700 \mathrm{~m}$. These orientations were also confirmed by the interpolation of $\mathrm{Pb}-\mathrm{Zn}-\mathrm{Cu}-\mathrm{Fe}(\%)$ contents map. These show contours with high concentrations of $\mathrm{Pb}-\mathrm{Zn}( \pm \mathrm{Cu})$ located along predominantly NE-SW and NW-SE zones. The highest values in Fe are essentially in a large area expanding NE and NW. These results suggest two main linear trends: NE-SW and NW-SE. These linear 
trends are similar to the directions of the main geophysical tectolineaments controlling mineralization. Thus, from this combined geoscience data, the analysis of the distribution of mineralized deposits and indices shows that the mineralization is guided by linear and structural trends in the margins of sedimentary basins: In the Setifian/Hodna, the spatial distribution of the mineralization is along NW-SE/EW axes, probably controlled by tecto-lineaments of the same direction 2) - In the Eastern Saharan Atlas, it is a distribution following deformation corridors of NE-SW/NW-SE orientation.

\section{Conclusion}

The processing of geological and geological data supplemented by geophysical and geostatistical analysis (interpolation maps of $\mathrm{Pb}-\mathrm{Zn}-\mathrm{Cu}-\mathrm{Fe}$ contents) in a geographic information system made it possible to specify the main geological environments and to identify structural trends (axes) controlling the mineralization of Sétifien/Hodna and the eastern Saharan Atlas. The mineralized deposits are preferentially located in the margins of the subsidence basins, near the accidents zones of the substrate [52]. The latter probably represent the underlying engine that has favored the circulation of mineralized fluids. In the Sétifian/Hodna, geophysical analysis shows that these same deposits are located near or along tecto-lineaments mainly of NW-SE/E-W orientation. In the eastern Saharan Atlas, mineralization appears to be controlled by NESW and NW-SE directional tecto-lineaments. Interpolation maps obtained from the geostatistical analysis (ordinary kriging) of $\mathrm{Pb}$ $\mathrm{Zn}-\mathrm{Cu}-\mathrm{Fe}$ concentrations (\%) show strong similarities. These axial trends (NE-SW/NW-SE) reflect the deformation corridors that have controlled the emplacement of mineralized deposits in these areas and may represent potential targets for mineral exploration.

\section{Acknowledgment}

The team wishes to thank the ORGM for having accepted to supply archival documents indispensable for this research.

\section{References}

1. Carranza EJM, Woldai T, Chikambwe EM (2005) Application of datadriven evidential belief functions to prospectivity mapping for aquamarine-bearing pegmatites, Lundazi District, Zambia. Natural Resources Research 14(1): 47-63.

2. Ziaii M, Abedi A, Ziaei M, Rouhani AK, Zendahdel A (2010) GIS modelling for $\mathrm{Au}-\mathrm{Pb}-\mathrm{Zn}$ potential mapping in torud-chah shirin area-Iran International Journal of Mining \& Environmental Issues 1(1).

3. Alok K, Porwal AK, Kreuzer OP (2010) Introduction to the special issue: Mineral prospectivity analysis and quantitative resource estimation. Ore Geology Reviews 38(3): 121-127.

4. Zuo R, Carranza EJM (2011) Support vector machine: A tool for mapping mineral prospectivity. Computers \& Geosciences 37(12): 1967-1975.

5. He B, Chen J, Chen C, Liu Y (2012) Mineral prospectivity mapping method integrating multi-sources geology spatial data sets and casebased reasoning. Journal of Geographic Information System 4(2): 77-85.

6. Joly A, Porwal A, Mccuaig TC (2012) Exploration targeting for orogenic gold deposits in the granites-tanami orogen: Mineral system analysis, targeting model and prospectivity analysis. Ore Geology Reviews 48: 349-383.
7. Porwal A, Carranza EJM, Hale M (2003) Artificial neural networks for mineral-potential mapping: A case study from Aravalli Province, Western India. Natural Resources Research 12(3): 155-171.

8. Tangestani MH, Moore F (2003) Mapping porphyry copper potential with a fuzzy model, northern Shahr-e-Babak, Iran. Australian Journal of Earth Sciences 50: 311-317.

9. Partington GA, Sale MJ (2004) Prospectivity mapping using GIS with publicly available earth science data - A new targeting tool being successfully used for exploration in New Zealand. Adelaide SA: 19-22.

10. Carranza EJM, Hale M, Faassen C (2008) Selection of coherent deposittype locations and their application in data-driven mineral prospectivity mapping. Ore Geology Reviews 33 (3-4): 536-558.

11. Carranza EJM, Hale M, Owusu EA (2009) Mapping of prospectivity and estimation of number of undiscovered prospects for lode gold, southwestern Ashanti Belt, Ghana. Miner Deposita 44(8): 915-938.

12. Carranza EJM (2010) From predictive mapping of mineral prospectivity to quantitative estimation of number of undiscovered prospects. Resource Geology 61(1): 30-51.

13. Nouri R, Afzal P, Arian M, Jafari M, Feizi F (2013) Reconnaissance of copper and gold mineralization using analytical hierarchy process (AHP) in the Rudbar 1:100,000 map sheet, northwest Iran. Journal of Mining and Metallurgy 49(1): 9-19.

14. Vila JM (1980) The alpine chain of northeastern Algeria and AlgerianTunisian borders. Thesis Doct of State Univ P and M Curie Paris VI, 665.

15.Wildi W (1983) The Tello-Rifain chain (algeria-morocco-tunisia): Structures, stratigraphy and evolution from the triassic to the miocene. Rev From geol Dynam and geogra Physics 24: 201-297.

16. Guiraud R (1990) The post-triassic evolution of the avant-pays of the alpine chains, after the study of the bassin du Hodna et des régions voisines: Thèse Doct Sci Univ Nice Mémoires n 3 Publ ONIG Alger 259.

17. Herkat M (1999) The sedimentology of the high sea level of the upper cretaceous Atlas Eastern Saharan and Aurès: Sequential stratigraphy, quantitative analysis of biocenoses, palaeogeographic evolution and geodynamic context. Thesis Doct State USTHB (FSTGAT) Algiers Algeria.

18. Laffite R (1939) Geological study of the Aures. Bull Serv Map geol Algérie $2^{\text {nd }}$ sé Stratigr Descript Région $N^{\circ} 15: 451$.

19. Aissaoui D (1984) Structures related to the south-atlas accident between biskra and djebel manndra, Algeria. Geometric and kinematic evolution Thesis $3^{\text {rd }}$ cycle, Strasbourg, France.

20. Addoum B (1995) The Saharan atlas of the south-east: Kinematics of folds overlaps and reconstruction of the basin of south-east constantine (confins algerian-tunisian). Thesis Doc Sc Univ Paris XI Center d'Orsay 200.

21. Kazi TN (1986) Geodynamic evolution of the North African border: The intraplaque domain North-Algerian. Megasequential approach Thesis Doct ès Sciences Univ Pau and the Adour countries.

22. Glacon J (1967) Research on geology and metal deposits of tell Setifien (Algeria). Bull Serv Geol Algeria 32(2).

23. Popov A (1968) Morphological types and distribution of zinc and lead deposits in Algeria. Ann Mines Geol Tunis 23: 103-203.

24. Touahri B (1987) Geochemistry and metallogeny of Pb-Zn mineralization in northern Algeria. Thesis Doct of State Univ P and M Curie Paris VI 1: 300 .

25. Perthuisot V (1992) The diapirs of the central and Eastern Maghreb: Various diapirs, results complex structural and petrogenetic evolution. Bull Soc Geol France 163(6): 751-760.

26.Zerdazi A (1990) Gravimetric study of the aïnm'lila mole and the northern Saharan Atlas (North-East of Algeria). Thesis Doct Es Sciences Faculty of Sciences Univ De Lausane 227. 
27. Aoudjehane M (1991) Distribution of Pb-Zn deposits and sideritic iron in the Algerian NE. In: Pagel LJ (Ed.), Source, Transportation and disposal of metals. Belkema Rotterdam pp. 419-422.

28. Bouzenoune A (1993) Peridiapiric mineralizations of calcareous Aptian: The iron carbonates of the hematite deposit of Ouenza (Eastern Algeria). PhD Thesis Univ Paris VI, France.

29. Boutaleb A, Afalfiz A, Aisa KO, Marignac Ch, Touahri B (2000) Metallogeny and geodynamic evolution of the Tellian chain in algeria. Bull Serv Geol Algeria Flight 11(1): 3-27.

30. Boutaleb A (2001) Pb-Zn mineralization of the sétifien-hodna domain Gitology, petrography of dolomites, microthermometry and metallogenic implications. Thesis Doct State USTHB (FSTGAT) Algeria.

31. Haddouche $\mathrm{O}$ (2010) The mineralization at $\mathrm{Ba}, \mathrm{Pb}-\mathrm{Zn}, \mathrm{Cu}, \mathrm{Hg}$ linked to the NE segment of djebel azreg-djebel khenchela (NE of Algeria): Geology, gitology and contribution of the study of inclusions fluids. PhD Thesis in Geology FSTGAT/USTHB p. 175.

32. Sami L (2011) Geochemical characterization of $\mathrm{Pb}-\mathrm{Zn}, \mathrm{F}, \mathrm{Ba}, \mathrm{Cu}, \mathrm{Fe}$ and $\mathrm{Hg}$ mineralization in the Algerian-Tunisian areas. Thesis Doct State USTHB Algiers Algeria p: 179.

33. Guiraud R, Bosworth B, Thierry J, Delplanque A (2005) Phanerozoic geological evolution of Northern and Central Africa: An overview. Journal of African Earth Sciences 43(1-3): 83-143.

34. Camoin G, Bouju JP, Maurin AF, Prthuisot V, Rouchy JM (1990) Relationship reefs-diapirs: The example of Senonian khenchela (Middle East Algeria). Bull Soc Geol la France 8(5): 831-841.

35. Perthuisot V, Rouvier H (1988) The metal-sulfur-water-hydrocarbonmicroorganism relationships and the genesis of sulphide and sulfur concentrations of evaporitic diapirs. In: Pélissonier H, Sureau JF (Eds.), Mobility and concentration of base metals in sedimentary cover: Manifestations, mechanisms, prospection. BRGM document 183: 269278.

36. Thibieroz J, Madre M (1976) The siderite deposit of jebel el Ouenza (Algeria) is controlled by a golg of the Aptian sea. Bull Soc Hist Nat North Africa Algiers 67(3-4): 126-150.

37. Touray JC (1989) Studies of fluid inclusions and modeling of the genesis of deposits of the type Mississippi Valley. Chronicle of mining research 495: $21-30$

38. Sverjensky DA (1986) Genesis of Mississipi valley type lead-zinc deposits. Annual Review of Earth and Planetary Science 14: 177-199.

39. Sangster DF (1990) Mississipi valley-type lead-zinc. In: Eckstrand OR, Sinclair WD, Thrope RI (Eds.), Geology of Canadian mineral deposit types. Geological Survey of Canada 8: 253-261.

40. Leach DL, Bradley D, Lewchuk MT, Symons DTA, De Marsily G, et al. (2001) Missipi Valley-type lead-zinc deposits trough geological timeimplications from recent age-dating research. Mineralium Deposita 36: 711-740.
41. Vila JM (1978) 1: 500,000 geological map of the alpine chain of eastern Algeria and the Algerian-Tunisian borders. CNRS-BEICIP.

42. Haddouche 0, Boutaleb A, Benhamoud I (2014) Structural context mineralization linked to the northern edge of the Aurès Mountains (NE of Algeria) and neighboring regions: Example of the BA-Pb $(\mathrm{Zn}-\mathrm{Cu})$ deposits of Ichmoul and Ain Mimoun. Bull of the Geological Service of Algeria Flight 25(1): 3-19.

43. Porwal A, Carranza EJM, Hale M (2006) Tectonostratigraphy and basemetal mineralization controls, Aravalli province (western India): New interpretations from geophysical data analysis. Ore geology reviews 29(3-4): 287-306

44. Jung Holden EJ, Wong JC, Kovesi P, Wedge D, Dentith M, et al. (2012) Identifying structural complexity in aeromagnetic data: An image analysis approach to greenfields gold exploration. Ore Geology Reviews 46: 47-59.

45. Chernicoff JC, Richards JP, Zappettini EO (2002) Crustal lineament control on magmatism and mineralization in northwestern Argentina: Geological, geophysical, and remote sensing evidence. Ore Geology Reviews 21(3-4): 127-155.

46. Bierlein FP, Murphy FC, Weinberg RF, Lees T (2006) Distribution of orogenic gold deposits in relation to fault zones and gravity gradients: Targeting tools applied to the Eastern Goldfields, Yilgarn Craton, Western Australia. Miner Deposita 41(2): 107-126.

47. Austin JR, Blenkinsop TG (2009) Local to regional scale structural controls on mineralisation and the importance of a major lineament in the eastern Mount Isa Inlier, Australia: Review and analysis with autocorrelation and weights of evidence. Ore Geology Reviews 35(3-4): 298-316.

48. Chen G, Cheng Q, Zuo R, Liu T, Xi Y (2015) Identifying gravity anomalies caused by granitic intrusions in nanling mineral district, China: A multifractal perspective. Geophys Prospect 63: 256-270.

49. Salvadore BS, Cornu S, King D (2002) Distribution of a trace element $(\mathrm{Cr})$ in soil developed on metamorphic rocks: Variability at the scale of a slope. CR Geoscience 334: 51-58.

50. Baize D, Saby N, Deslais W, Bispo A, Feix I (2006) Total and pseudototal analyzes of trace elements in soils. Study and Management of Soils 13(3): 181-200.

51. Youan Ta M, Yao K, Bakar D, Lasm ZO, Lasm T, et al. (2015) Mapping of potential areas for the implementation of boreholes with large flows in a fissure medium by multi-criteria analysis of the department of Oume (west-central Ivory Coast). Larhyss 23: 155-181.

52. Rouvier H, Perthuisot V, Mansouri A (1985) Pb-Zn deposits and salt bearing diapirs in Southern Europe and North Africa. Econ Geol 80: 666687. 